\title{
The Precision Of The Giving Of The Drug Based On Service Identifikation Of Patien Compliance At "Darmayu" General Hospital Ponorogo
}

\author{
Agusta Dian Ellina ${ }^{1}$, Suwarno ${ }^{2}$, Alfian Fawzi ${ }^{3}$ \\ ${ }^{1,3}$ Stikes Surya Mitra Husada Kediri \\ ${ }^{2}$ RSU Darmayu Ponorogo \\ Corresponding author: agustadian85@gmail.com
}

\begin{abstract}
Background: The research was distributed by drug services granting conditions up to this moment there are still many problems. As for the problem of the research is "whether the compliance of nurses in identifying influence on accuracy in the service of dispensing".

Purpose: Aim of this research is to know the level of compliance officers perform identification before providing the service of medicine, knowing compliance do identification relationship and analyze correctness of granting of service remedy with precision identification in "Darmayu" general hospital Ponorogo.

Methods: In this study data collected through questionnaire method against 40 people the respondents admitted in "Darmayu" general hospital using the aksidental method, Ponorogo for knowing the responses of respondents to each variable. Then conducted an analysis of the data obtained in the form of quantitative analysis. Quantitative analysis includes the test validity and reliability, as well as test the correlation of Phi.

Result: Of research results, data the respondents obtained shows that the level of accuracy of the perwat in the service of the drug still has not been fullest is demonstrated from 40 respondents, there were 22 stating the precision. Likewise, the level of compliance of nurses in conducting identification is still lacking, from 40 respondents, 14 respondents declared not obedient in doing identification. The results of the analysis of the compliance officers do get that the identification of the effect on the precision in the service of medicine. Hypothesis testing using the test correlation of Phi showed that independent variables examined is proven to significantly affect the dependent variable.

Conclusion: Patient safety incidents can be prevented by the presence of the nurse in conducting compliance identification as well as precision in running the SOP. Sosiaisasi and high awareness of nurses on the importance of obedience and compliance in carrying out procedures will greatly affect the success of a service to patients at home sick.
\end{abstract}

Keyword: Patient safety, Nurse compliance, Patient, Identification

Received: February 03, 2018; Revised February 24, 2018; Accepted March 10, 2018

How to Cite: Ellina, A.D., Suwarno., \& Fawzi, A. (2018). The Precision Of The Giving Of The Drug Based On Service Identifikation Of Patien Compliance At "Darmayu" General Hospital Ponorogo. Journal Of Nursing Practice. 1(2). 7-11 


\section{BACKGROUND}

Patient safety is part of a priority in nursing services. Nurses as the front guard in health services are required to always provide quality services and ensure patient safety. Many cases in health services occur from nursing actions performed by nurses not in accordance with the Standard Operating Procedures (SPO) that has been set. The Institute of Medicine in the United States reported that in Utah and Colorado there was an adverse event of $2.9 \%$, of which $6.6 \%$ of them died. While in New York Unwanted Event (KTD) was 3.7\% with mortality rate $13.6 \%$. The number of deaths due to KTD in hospitalized patients across America amounting to 33.6 million per year ranged from 44,000 to 98,000 per year. WHO publication in 2004, collecting hospital research figures in various countries: America, England, Denmark, and Australia, found KTD with a range of 3.2 to $16.6 \%$. With these data, various countries immediately conduct research and develop the Patient Safety System (MOH RI, 2011).

The impact caused by frequent KTD, KNC, KPC and Senetinel event is very complex, for patients the impact is going to be the length of hospitalization (ALOS), with the increasing number of days of care will also increase the cost (Cost). The most dangerous impact of death is very detrimental to the patient due to not doing the procedure as specified. In Indonesia, according to MOHRI (2011), data on KTD and KNC are still scarce, but on the other hand there is an increase in mal-practice allegations that are not necessarily in accordance with the final verification. Incidence of patient safety breach $28,3 \%$ done by nurse. Therefore, the nurse as one of the implementers has great potential in making a mistake if it does not have the knowledge and awareness is high that the actions performed will have an effect on the patient. The results of preliminary survey of researchers obtained from the Patient Safety Committee at the research site on November 2, 2016, has been socialized program 6 target patient safety but still not well understood and implemented about the patient's safety, this can be seen from the front office or information who has not performed a record of identity well where in the medical record document the patient has not listed the birth date of the patient, In the ER, the patient's identity bracelet is still listed patient's age not the date of birth, also the patient has not been given education / explanation about the benefits of the installation of the bracelet, identifier not installed or removed or covered. In the treatment room is also still common where the officer before the action did not do a good identification.

From the incident report data on the error in the provision of drug services due to the lack of proper identification of patient identification procedures, indicating that in the last 3 months (July, August, September) there were 4 cases of KTD (Unexpected events) identification. this occurs because the patient's name is the same ( 2 occasions), Patient moved bed / bed (1 event), one patient / patient sealed closed bracelet (1 event) (PMKP RSU Data "Darmayu").

\section{OBJECTIVE}

Aim of this research is to know the level of compliance officers perform identification before providing the service of medicine, knowing compliance do identification relationship and analyze correctness of granting of service remedy with precision identification in "Darmayu" general hospital Ponorogo

\section{METHODS}

This type of research uses descriptive quantitative research design based on a philosophy of positivism that emphasizes objective phenomena and is studied quantitatively. The 
design objectivity maximization of this research is done by using numbers, statistical processing, structure and controlled experiments. There are several research methods that can be incorporated into non-experimental quantitative research. The research design used in this research is by Cros Sectional approach which is a research where the cause or risk variable and the effect or case happened on the research object is measured and collected by stimulant, moment or one time at one time / Setiadi, 2009).

this study taking sampling is aksidental based on the characteristics of individual traits that will be studied in accordance with the consideration of the researcher so that it can represent the population are: patients with age $\geq 18$ Th or already married, patients can read and write patients who are willing to become respondents.

For scoring independent and dependent variables using Nominal scale.

Score 1: If the answer is never

2: If answer sometimes

3: If answer always

To get the value or the number of compliance and non-compliance, the researcher uses technical data analysis with the calculation of Mean. Mean is an average value that can represent a set of representative data. The mean of compliance and accuracy in this study is 14. If the total score is $\leq 14$ then the code is 1 (not petak / not exact), utuk total score $\geq 14$ then the code 2 (obedient / precise)

In this study validation test using 10 respondents who were hospitalized in Muslimat General Hospital Ahmad Yani Ponorogo. By using computer program

Reliability test is the level of stability of a measuring device in measuring a symptom / occurrence. The higher the reliability of a measuring device, the more stable the measuring device is. According to Nunnaly (1967) in Ghozali (2001), a construct is said to be reliable if it gives a Cronbach Alpha value $>0.6$.

\section{RESULTS}

Table 1. Result of respondent's answer to variable compliance identification

\begin{tabular}{ccc}
\hline & obedient & not obey \\
\hline Responden & 22 & 18 \\
\hline
\end{tabular}

Table 2. Results of respondents' answers to the variables of the accuracy of drug services

\begin{tabular}{ccc}
\hline & obedient & not obey \\
\hline Responden & 26 & 14
\end{tabular}

Table 3. Phi Corelation test

\begin{tabular}{|c|c|c|c|c|c|}
\hline \multicolumn{6}{|c|}{ Tabel Uji korelasi Phi } \\
\hline & Value & $\mathrm{df}$ & $\begin{array}{c}\text { Asymp. } \\
\text { Sig. (2- } \\
\text { sided) }\end{array}$ & $\begin{array}{c}\text { Exact } \\
\text { Sig. (2- } \\
\text { sided) }\end{array}$ & $\begin{array}{c}\text { Exact } \\
\text { Sig. (1- } \\
\text { sided) }\end{array}$ \\
\hline Pearson Chi-Square & $9.808 \mathrm{a}$ & 1 & 0.002 & \multirow{6}{*}{0.003} & \multirow{6}{*}{0.002} \\
\hline $\begin{array}{l}\text { Continuity } \\
\text { Correctionb }\end{array}$ & 7.832 & 1 & 0.005 & & \\
\hline Likelihood Ratio & 10.213 & 1 & 0.001 & & \\
\hline Fisher's Exact Test & & & & & \\
\hline $\begin{array}{l}\text { Linear-by-Linear } \\
\text { Association }\end{array}$ & 9.563 & 1 & 0.002 & & \\
\hline $\mathrm{N}$ of Valid Casesb & 40 & & & & \\
\hline
\end{tabular}




\section{DISCUSSION}

\section{Compliance Level of Patient Identification at RSU "Darmayu"}

From the result of the questionnaire about the identification compliance given to the respondent on the identification of the patient conducted by the nurse, the result of 22 respondents $(55 \%)$ said that the officer did the identification before the drug administration and 18 respondents $(45 \%)$ said that the nurse did not identify before drug. According to Kaur et al (2008) compliance from health workers relate to the knowledge they have. This knowledge will then be derived in the form of attitudes or behavior of health workers in the face of patients. Compliance in the standard precautions here is closely related to the behavior of health workers in preventing the occurrence of infection when dealing with patients.

Looking at the facts and theories from previous research indicates that many factors that influence nurse compliance in identifying them, less knowledge of nurses about what and how to identify before taking action.

In addition, the nurse's awareness in understanding the importance of identifying prior to the action is still lacking, it is based on the hospital periodically who has conducted socialization about patient safety which includes identifying before taking action.

Another factor that may affect the level of nurse compliance is the lack of supervision by the boss or supervisor of the services performed by the ataf so that the assurance that the policies, procedures and SPO are well run is lacking.

\section{Level of Accuracy of Drug Delivery Service in RSU "Darmayu" Ponorogo}

From respondent data showed that the accuracy in drug service resulted 26 respondents $(65 \%)$ of respondents stated that the nurse was right in giving medicine service and 14 respondents $(35 \%)$ stated that the nurse was not appropriate in providing drug service.

Based on the researcher's observation when giving questionnaires to be filled, seen some respondents are still confused because the respondents did not pay much attention to what the nurse did when giving medicine.

By looking at the results of research conducted as well as from the facts and theories above it is found that the accuracy in the provision of drug services based on compliance in applying the principle 6 can be influenced by the level of knowledge, education and full awareness by the nurses about the impact of behavior caused by inaccuracy in providing drug services becomes very important. This is based on respondents' answers where the majority answered sometimes, meaning that the nurse has been socialized but not orderly in running it.

\section{Compliance Relation Analysis Identification with the Accuracy of Drug Delivery Services at RSU "Darmayu" Ponorogo}

From the data of respondents from 40 respondents $75 \%$ showed a relationship where 30 respondents said that the nurses are obedient in identifying also meyatakan appropriate in providing drug services as well as vice versa. While the respondents who say nurses obedient in identifying but not appropriate in providing drug services or vice versa a number of 10 respondents.

By looking at the results of data analysis shows that there is a significant relationship between compliance in identifying with accuracy in the provision of drug services. The more obedient the officer in identifying the accuracy in the drug service will be better too. Conversely the accuracy of drug services will decrease if the level of compliance officers in the identification also decreased. 


\section{CONCLUSION}

The level of nurse compliance in the identification is still lacking, this is due to lack of understanding of the importance of identifying and still weak supervisory supervisor on the implementation of the established procedures.

In the application of the principle of 6 right by the nurse is still not optimal, this is caused by a lack of understanding of the way the implementation of these 6 principles and periodic socialization has not done and regular evaluation.

Based on statistical test by using Phi correlation test by using SPSS program got $\alpha=0,05$ $\geq \mathrm{P}$ value value that is: 0,003 or Ha accepted, Ho rejected in other words there is a very significant relationship between compliance to identify with the accuracy of drug service delivery in RSU "Darmayu" Ponorogo.

\section{REFERENCES}

Bernadeta Dece Harus ; Ani Sutriningsih 2015, Pengetahuan Perawat Tentang Keselamatan Pasien dengan Pelaksanaan prosedur Keselamatan Pasien di Rumah Sakit, Jurnal CARE Vol. 3 No 1, http://ejournal.unsrat.ac.id/index.php/ebiomedik/issue/view/838 2015.

Cahyono, J.B 2010. Membangun Budaya Keselamatan Pasien Dalam Praktek Kedokteran. Yogyakarta : Kanisius.

KARS, 2011. Standar Akreditasi Rumah Sakit, Jakarta : Departemen Kesehatan RI.

Kemenkes RI. 2008. Panduan Nasional Keselamatan Pasien Rumah Sakit (Patient Safety): Utamakan Keselamatan Pasien. Jakarta: Depkes RI.

KKP-RS. 2008. Panduan Nasional Keselamatan Pasien Rumah Sakit. Jakarta: Depkes RI.

Kozier.Erb.Berman.Snyder, 2010, Fundamental Keperawatan, Jakarta : EGC

Persi. 2011. Join Commution International Standar Akreditasi RS.Edisi 4. Jakarta Gramedia

PMK RI Nomor 1691/MENKES/PER/VIII/2011 tentang Keselamatan Pasien Rumah Sakit.

Rekam Medis RSU “Darmayu” ponorogo 2016, Laporan insiden keselamatan pasien.

Undang Undang Nomor 44 Tahun 2009 tentang Rumah Sakit Dona Dwi Ekawati, 2013 Evaluasi penerapan identifikasi pasien dibangsal rawat inap RSI Siti Aisyah Madiun 